\title{
The Subversion of Francoist Rhetoric in Blas de Otero's Pido la paz y la palabra
}

\author{
Samuel O'Donoghue ${ }^{1}$ (1)
}

Accepted: 31 May 2021 / Published online: 27 August 2021

(C) The Author(s) 2021, corrected publication 2022

\begin{abstract}
This article explores the ways in which socially and politically engaged poetry challenged the Franco regime in mid-twentieth-century Spain. A close reading of the work of Blas de Otero reveals how this poet crafts a discordant voice by alluding to, mimicking, and subverting the very myths and rhetoric of Franco's regime. Working against the strictures of state censorship, Blas de Otero usurps the linguistic idiosyncrasies and thematic tropes characteristic of Francoist discourse and redeploys them in a distorted form in his poetry of protest. This article shows ultimately how poets such as Otero were able to engage with the social realities the regime was anxious to conceal by contesting one of the most conspicuous manifestations of the regime's power-its monopoly of public discourse - and how such writers were able thereby to contribute to the erosion of the regime's authority and to its discredit among cultivated readers in 1950s Spain.
\end{abstract}

Keywords Blas de Otero $\cdot$ Poetry $\cdot$ Dissidence $\cdot$ Subversion $\cdot$ Parody $\cdot$ Franco $\cdot$ Spain

Spain's cultural landscape in the aftermath of the civil war was desolate. ${ }^{1}$ The literary vanguard had been associated with the Republican side in the conflict, and the loss of those artistic luminaries who were either dead or in exile was aggravated by the endeavour to amputate the remnants of their legacy. In Spanish poetry, the revival of classical metrical forms and the vogue of garcilasismo heralded a return to traditionalism that was in harmony with the founding myths of National

\footnotetext{
${ }^{1}$ This research was supported by Poesía Actual y Política (II): Conflictos sociales y dialogismos poéticos (PID2019-105709RB-I00), a research project funded by the Ministerio de Ciencia, Innovación y Universidades (Spain). The article builds on a paper presented at Against the Grain: The Ethics, Politics and Poetics of Contrarian Speech, a symposium held at the University of Amsterdam on 5-7 June 2019. I am very grateful to the symposium organizers and fellow participants for their comments on the earlier version of this study.
}

Samuel O'Donoghue

s.odonoghue1@lancaster.ac.uk

1 Department of Languages \& Cultures, Lancaster University, Lancaster LA1 4YD, UK 
Catholicism. It was not until the 1950s that Spanish poets began truly to take stock of and to protest against the desperate social realities surrounding them. This article examines the work of one of Spain's most celebrated poets of the period, Blas de Otero, with the aim of illustrating how this poet crafts a discordant voice by alluding to, mimicking, and subverting the very myths and rhetoric of Franco's regime. Working within the strictures of state censorship, Blas de Otero usurps the linguistic idiosyncrasies and thematic tropes characteristic of Francoist discourse and redeploys them in a distorted form in his poetry of protest. What emerges ultimately in Otero's poetry is a subtle critique of Francoism forged through an appropriation and subversion of the linguistic tools of the oppressor.

In the absence of a free press that could publicize the economic and social misery of the "años de hambre" in the 1940s and of Spain's lethargic and uneven recovery in the 1950s, cultural practices attained an important role in social commentary. The social realist novel emerged in Spain at a time when the press was neutered by the continued application of pre-publication censorship, which had been introduced during the war by the 1938 Ley de Prensa, and by the strict supervision of the Ministerio de Información y Turismo whose "consignas," or directives, shaped the news agenda and turned papers into informational organs of the regime. While also subjected to censorship, elite cultural forms were not policed with the same diligence, with the result that literature became an important medium for the portrayal of social realities and for the expression of dissent. Jo Labanyi (1995: 214) describes realism as an expedient to which Spanish writers and filmmakers turned to overcome the constraints of a "shackled press." However, at the same time, not all cultural forms were met with equal indulgence among the censors. Labanyi distinguishes between the regime's treatment of elite culture, on one hand, and popular culture, on the other:

Literary censorship [...] was lenient with high cultural forms. Poetry became a vehicle for social protest in the 1950 s because dissidence could be tolerated in a minority genre. A surprising number of 1950s social realist novels got through the censors [...] Doubtful texts were often allowed in small print-runs or luxury editions. But popular romances and adventure stories were strictly controlled, as were historical and political texts in cheap editions. (1995: 211)

The rationalization of the regime's efforts in policing the written word meant that while certain media were subject to stricter control, others were habitually overlooked and enjoyed relative freedom. Andrew P. Debicki emphasizes that poetry in particular was afforded greater autonomy from the regime's ideological dictates precisely because of its status as a minority genre:

It may at first seem puzzling that poetry, of all genres, should become so dominated by the expression of social concern and protest. Yet there are reasons for it [...] [P]oetry was the genre least likely to draw the veto of the censors in the 1940s and 1950s. A play that might be seen on stage, an essay that could be read widely, or even a novel published in many copies would attract careful scrutiny from the censors, leading frequently to rejection. A volume of poetry or a small magazine, less widely distributed and considered more personal, 
had a better chance of slipping by [...] Poetry became, therefore, the protest genre of choice in the Spain of the period. (1999: 191)

Blas de Otero's Pido la paz y la palabra (1955) made it into print without the interference of state censorship. The material thought most egregious and liable to raise the hackles of Spain's cultural police had already been expunged during the editing process. Even still, the fact that the collection made it past the censors unscathed is likely because of an administrative oversight that meant the manuscript was approved without having been read (Neira, 1987: 256). Julio Neira (1987: 255) surmises that the collection would not have been published had the censors been more diligent, but such bureaucratic negligence was possible only with a literary medium that was not high on the censors' list of priorities. Labanyi suggests that the fact that cultural expressions of political dissidence made it into print is not an oversight on the censors' part but rather evidence of the regime's acuity: "It is easy to dismiss the censors as stupid, but their tolerance of high artforms suggests they knew what they were doing. It was not until the 1960s that intellectuals started to realize what the censors had always known: that élite culture is, sadly, not a political threat" (1995: 214). While poetry of protest certainly did not pose a threat to the regime in the immediate context of its publication, it contributed to galvanizing the dissident energies that eroded Francoist legitimacy in the long run. Cultural works were an important locus of opposition for the resurgent liberal intellectual class that eventually starved the Franco regime of a sympathetic elite that might have ensured the survival of the regime beyond the dictator's death. Opposition to Francoism among Spanish intellectuals and the next generation of elites constituted a silent resistance-to use a felicitous expression coined by the cultural historian Jordi Gracia (2004)—which began to gain traction particularly from the mid-1950s. The student protests of February 1956 were an early manifestation of the generational cleavage that testified to the ideological and cultural bankruptcy of Francoism:

A la altura de 1950 ninguna de las peores expresiones del nacional-catolicismo ha retrocedido en su obsceno ejercicio de poder ideológico y control cultural y sin embargo algunas cosas van a empezar a cambiar [...] Una juventud universitaria que había vegetado en un estado de asfixia cultural [expresaba] un desencanto ideológico del falangismo [que] comenzaba a ser alarmante. (Gracia, 2006: 46)

The escalation of unrest on university campuses was consonant with the maturation of a dissident intelligentsia and of the liberal democratic culture they embodied. The existence of this dissident culture was instrumental in the transition to democracy after Franco's death, given that the social impetus for the transition was nurtured by the cultural recovery of liberal tradition, which reinforced the subversive tendencies in other areas of public life:

Los circuitos intelectuales, librescos y humanos [...] permitieron a unos cuantos jóvenes sacudirse de encima en los años cincuenta la hipoteca totalitaria y dogmática de una España premoderna, fascista o nacional- 
católica, para ir a buscar por su cuenta y sin demasiadas fuentes fiables, sin maestros activos y verdaderos, la reanudación de una modernidad que crecía y maduraba fuera de España, y había crecido y madurado antes de la catástrofe, en plena República. (Gracia, 2006: 10)

Intellectual liberalization expedited social liberalization in Spain and is enmeshed in the network of dissident energies that corroded the National-Catholic cultural project and laid the foundations for the transition to democracy.

In the context of 1950s Spain, poetry was then perhaps not as innocuous as it might at first seem. While its impact is hard to measure, the kind of poetry that engaged not just with the social realities the regime was anxious to conceal but that challenged one of the most conspicuous manifestations of the regime's powerits monopoly of public discourse-was able to contribute to the erosion of the regime's authority and to its discredit among cultivated readers. An acute observer of National-Catholic Spain, the memorialist and poet Carlos Barral, who was also influential in contesting the regime's authority over Spanish culture in his work as a publisher, testifies to the insidiousness of Francoist rhetoric in the post-war period and to the role of this same rhetoric in the process of his politicization as a reaction against the regime's propaganda:

En nuestras primeras pasiones políticas no contaban tanto las delgadas ideas como la aversión, una sana y sólida repugnancia por el mundo que intentaban imponernos. La sordidez de la retórica fascista, la mediocridad de sus mentiras y de sus embustes, nos hacían irreconciliables enemigos de aquel poder soez, de aquel orden carcelario, y la nostalgia de una República que no habíamos conocido y acerca de la cual, probablemente, no habíamos oído un solo juicio objetivo, nos hacía filomarxistas o anarcoides. (Barral, 2001: 245)

Cultural forms that were attuned to the contemptible nature of the rhetoric denounced by Barral epitomize the subversive potential of artistic creation in midtwentieth-century Spain.

This article focuses specifically on Blas de Otero's celebrated collection Pido la paz y la palabra, which was published in 1955 and marked a turn toward more preeminently social concerns in Otero's work. In 1952 the poet had spent a year living among exiled Spanish communists in Paris. His return to Spain coincided with a rekindled sense of solidarity with the working class and a renewed preoccupation with social justice. Otero's development as a poet in the years after the Spanish Civil War was consonant with the trajectory followed by other poets of the period. The onset of the war had coincided with the four-hundredth anniversary of the death of Garcilaso de la Vega, and in the early postwar period, Spanish poets turned to the celebrated soldier-poet of the Renaissance for inspiration. One of the most perceptive commentators on the poetry of the period and indeed one of Otero's earliest and most astute critics, the linguist Emilio Alarcos Llorach (1997: 22-23) suggests that Garcilaso was a spiritual narcotic in an era of strife. A preoccupation with formalism and with the musicality of dainty, melodic verses enabled poets to evade the crude realities of a ravaged and resentful country. There was also a resurgence of religious poetry in the period, as poets sought refuge in a transcendental plane of reality 
beyond the tumultuous historical moment. Blas de Otero's Cántico espiritual (1942) dates from precisely this period. Cántico espiritual is a homage to San Juan de la Cruz, the sixteenth-century Spanish mystic poet and saint, co-founder of the order of the Discalced Carmelites with Santa Teresa de Jesús. Garcilaso and Juan de la Cruz were the cultural companions of a Francoist ideology that presented the regime as heir to Spain's imperial past. Franco's legitimacy was bound up with the foundational myths of the Spanish nation state. The civil war had been a crusade modelled in the image of the Reconquista that had reclaimed Iberia from the Moors between 711 and 1492. As Caudillo of a unified Spain and with the geopolitical order in flux during World War II, Franco envisaged himself as a modern-day Charles V or Philip II who would restore the country to the height of its imperial power (Preston, 2014: 95). The cultural capital of Spain's Golden Age artists in the post-war period was the logical result of the ideology of National Catholicism. Garcilaso had fought in Charles V's bloody European campaigns and Juan de la Cruz was doctor of the Catholic Church, associated with the fellow mystic Santa Teresa de Jesús, whose severed hand contained within its reliquary Franco kept in his possession until his death. It is understandable why poets such as Garcilaso and Juan de la Cruz filled the void left by the illustrious Generación del 27, many of whom were either exiled or dead.

Blas de Otero's fascination with San Juan de la Cruz in the immediate postwar period testifies to his accommodation with the poetic currents of the time and also to his religious fervour. However, his work from the 1950s onward marks a break with the religiosity of his earlier work and heralds a newfound forthrightness in his attitude toward the regime. Religious imagery and language still appear in Otero's later poetry but they are employed in an ironic and irreverent fashion. ${ }^{2}$ In this later poetry, Otero's use of biblical allusion is subsumed within a wider project of political and social engagement. Otero condemns the social injustices to which his poetic persona bears witness and in so doing mounts a damning critique of the political institutions that preside over this abjection. Otero's critique of Francoism is particularly effective because of the way in which it parodies the regime's pious and nationalistic rhetoric. Otero's poetry is a polyphony of literary and popular sources. ${ }^{3}$ Otero borrows liberally from the poets and writers he admires and he repurposes everyday language and popular expressions. Amid this composite of the literary and popular, his use of Francoist rhetoric constitutes a salient category of allusion and linguistic borrowing.

Otero's use of Francoist rhetoric is discernible particularly in the poem "Sobre esta piedra edificaré" from Pido la paz y la palabra:

Testigo soy de ti, tierra en los ojos,

\footnotetext{
${ }^{2}$ On the different phases of Otero's poetic development and on the poet's use of religious imagery, see Lucía Montejo Gurruchaga (1998). On the subversive qualities of Otero's parody of biblical language, see Juan José Lanz (2008: 145-47).

${ }^{3}$ Otero's use of other poets' work and of popular language, including refrains and colloquialisms, has been well documented by critics. See Alarcos Llorach on Otero's use of set phrases and popular expressions (1997: 69-75) and on the poet's allusions to works by San Juan de la Cruz, Fray Luis de León, and Rubén Darío, among others (1997: 75-77). See also Carmen Barbosa-Torralbo (1994: 41-47, 101-29).
} 
patria aprendida, línea de mis párpados, lóbrega letra que le entró con sangre a la caligrafía de mis labios.

Y digo el gesto tuyo, doy detalles del rostro, los regalo amargamente al viento en estas hojas.

Oh piedra hendida. Tú. Piedra de escándalo.

Retrocedida España, agua sin vaso, cuando hay agua; vaso sin agua, cuando hay sed. "Dios, qué buen vasallo, si oviesse buen..."

Silencio.

(Otero, 2016: 232)

The title of the poem comes from the Gospel of Matthew, specifically the Confession of Peter, in which the apostle proclaims Jesus as the Christ, or messiah. Jesus rewards this declaration of his divinity by conferring on Peter a preeminent position as a corner stone in the foundation of the Church. The verse puns on the meaning of Peter's newly given name: "And I say also unto thee, That thou art Peter, and upon this rock I will build my church; and the gates of hell shall not prevail against it" (Matthew 16:18, KJV). In the title of his poem Otero elides the complement of the verb "edificar," leaving out the words "mi iglesia," and therefore raises the question of what exactly the poetic speaker intends to build. The elision of part of the biblical quotation might seem unremarkable at first. However, seen in the context of the end of the poem in which ellipsis is used in a more patently subversive fashion, Otero's excision of part of the biblical verse is telling. As with the word "señor" in the penultimate line of the poem, Otero uses the act of erasure to draw attention to the words that are absent. The Church is not mentioned explicitly in the poem but it is nevertheless the implied target of Otero's scorn. In another poem from the collection, "Biotz-Begietan," Otero takes aim at the Church and denounces its complicity with Nationalist brutality: "misteriosas sandalias I aliándose a las sombras del romero I y el laurel asesino" (2016: 246). Here the clergy are represented through synecdoche by the sandals they wear, in the same way as Franco's Nationalist forces are symbolized by the laurels that crown their triumph. In an earlier version of the poem, the attack on the Church was more explicit. However, prior to publication Otero removed the offending epithet that had initially been used to qualify the word "sandalias," replacing the word "religiosas" with "misteriosas" in an apprehensive act of self-censorship. ${ }^{4}$ In National-Catholic Spain, an attack on the Church was an

\footnotetext{
4 On Otero's self-confessed fears about certain passages in Pido la paz y la palabra, see Alarcos Llorach's account of their correspondence (1997: 11). For the original version of "Biotz-Begietan", see Alarcos Llorach (1997: 20).
} 
attack on the moral foundations of the regime itself. The regime's censors tended to be priests, and works proposed for publication in Franco's Spain were vetted to ensure they were compatible with Catholic orthodoxy. Otero's subtle manipulation of biblical quotation in "Sobre esta piedra edificaré" calls attention to the absence of moral authority in Spain. The foundations on which the Church is built are fractured. The solid bedrock on which Jesus entrusts the establishment of the Church is, in Otero's poem, a "piedra hendida" and a "piedra de escándalo," wreathed in ignominy. The poetic speaker declares an ambition to build an alternative moral order for a nation that has lost its way. Thus he establishes himself as witness to the decay in the first line of the poem: "Testigo soy de ti." The land he discovers before his eyes is an alien world whose contours the poetic speaker will have to relearn. In the first and second stanzas, the speaker describes the process of coming to terms with and recording the blood-soaked, funereal scenes of his homeland. In these selfreflexive verses, the poetic persona portrays the process of composition and hints at the cathartic impulse behind the act of writing, through which he hopes to free himself from these tormenting phantoms: "los regalo I amargamente al viento en estas hojas."

The poetic speaker's sense of alienation from his homeland is transmitted in the ironic "patria aprendida" of the second line. The word "patria" was one of the hallowed concepts of Francoist discourse. In his speeches of the civil- and post-war periods, Franco made heavy use of abstract nouns, such as "doctrina," "fe," "historia," "misión," "patria," "paz" (Eiroa San Francisco, 2012: 115-16). Similar abstract concepts recur in Pido la paz y la palabra, notably in the title of the collection itself. The words "patria" and "paz" appear in numerous poems. "Historia"-both with and without the initial grandiose majuscule, which was one of the regime's favoured rhetorical flourishes - appears in "Hija de Yago" (Otero, 2016: 233) and with a lowercase initial letter in other poems. Other formulations frequent in the linguistic repertoire of the regime, such as "vencer" and "Victoria," also appear in Pido la paz y la palabra, as do idioms derived from Catholic doctrine. The expression "patria aprendida" suggests a disparity between the poetic persona's memory of his homeland and the reality that now appears before his eyes. There is a clearly demarcated before and after in the speaker's perception of Spain, and the poem transmits a sense of mourning for the world that has been lost: "lóbrega letra que le entró con sangre I a la caligrafía de mis labios." The speaker's testimony of the land has been embittered by the experience of bloodshed. He has had to relearn the lineaments of this changed land and acquire a new poetic language with which to express it. The phrase "patria aprendida" also evokes the gulf between the speaker's understanding of his homeland and the image of Spain projected by the regime with its characteristically baroque style and its insistence on immutable and eternal essences. In National-Catholic dogma, "patria" connotes a corporatist social and political structure in which authority radiates down from God to the Caudillo and henceforth to the paterfamilias. The word evokes a duty of obeisance to the new political order, but in Pido la paz y la palabra, "patria" tends to appear with an overriding sense of melancholy. There is the "rostro I puro y terrible de mi patria" (Otero, 2016: 231), the "patria despeinada en llanto" (2016: 239), the "patria, árbol de sangre" (2016: 245), the "patria, árbol arrastrado I sobre los ríos" (2016: 247), the "patria 
árida y triste" (2016: 250). Most telling is the "patria del hombre" (Otero, 2016: 241 , which gives a sense of the contrast between the regime's use of the word and Otero's. For Otero, the word is not synonymous with authority and duty, rather it encompasses a heterogeneous assembly of people and places across a dejected and subjugated land. The aura of melancholy that suffuses the word derives from the painful memory of another time, and there are a number of poems in the collection that strive to recapture the primordial sense of wonder inspired by different places and their people. In "Espejo de España," "Aceñas," "En el corazón y en los ojos," and "Lo traigo andado," the speaker luxuriates in the toponymical riches of the land, reeling off long lists of treasured places (Otero, 2016: 233-34, 234, 237, 251-52).

A more conspicuous allusion to the regime's rhetoric in "Sobre esta piedra edificaré" occurs at the beginning of the third stanza. "¡Arriba España!” is a distinctive Francoist slogan that was popularized by the Falange in their emulation of fascist movements in Germany and Italy. It was the Nationalists' call to arms during the civil war and it survived as a patriotic cry of enthusiasm well into the years of the dictatorship and beyond. ${ }^{5}$ The writer José María Pemán, a fervent adherent to the Nationalist cause, reflected on the meaning of the battle cry in his 1939 history of Spain. Pemán believed that the slogan embodied the providential duty of the nation to return to its sacred path from which it had deviated under the Republic. "Arriba" implied a return to the lofty ideals that had guided Spain throughout its history, and the slogan denoted, in particular, a spiritual movement upward to God:

Ella [la victoria en la guerra civil] será la vuelta de España a sí misma: a su camino y a su Historia. Porque la Historia que acabamos de contar no ha sido más que eso: una lucha constante por los más altos ideales del Espíritu. No servimos para cosas bajas, pequeñas o menudas. No servimos más que para las cosas altas y grandes. Por eso cuando decimos “Arriba España," en esas dos palabras, a un tiempo, resumimos nuestra Historia y ciframos nuestra esperanza. Porque lo que queremos es que España vuelva a "su sitio": al sitio que la Historia le señala. Y el sitio es ese: "Arriba." Es decir, cerca del espíritu, del ideal, de la fe... Cerca, sobre todo, de Dios. (Pemán, 1939)

Blas de Otero's apostrophe to "Retrocedida España" evokes the Falangist catchphrase with its vague phonetic resemblance and similar exclamatory potency. In the Francoist slogan "arriba" is an adverb that performs a function of both exaltation-hailing Spain — and exhortation-enjoining others to pay homage to the country and to contribute to the Nationalist project. Otero's "retrocedida" is a participle. On a grammatical level, the word carries out a basic adjectival function. However, "retrocedida" does not merely describe Spain. If Otero had wanted simply to refer to the country as backward, then he might have used any one of numerous other, more familiar lexical choices to transmit the idea. Like "arriba," "retrocedida" conveys a sense of movement and direction. It seems likely that the line "Retrocedida España" was a conscious echo of the Falangist slogan. Resembling a rallying cry, the apostrophe is set off on a separate line to heighten its exclamatory force. While

\footnotetext{
${ }^{5}$ On the origins of the slogan, see Stanley Payne (1999: 63, 100).
} 
the Nationalist slogan suggests progress toward some providential destiny, Otero's parody shows a nation in decline and a people in retreat.

Francoist slogans are the subject of parody also in "Hija de Yago" (Otero, 2016: 232-33), another of the more ostensibly subversive poems in Pido la paz y la palabra, which is located immediately after "Sobre esta piedra edificaré" in the collection. In the first edition Otero expurgated parts of "Hija de Yago" in an act of preemptive self-censorship: from the eighth line of the poem the words "de América adormida" were removed, as was the entirety of the thirteenth line, "Alángeles y arcángeles se juntan contra el hombre" (Otero, 1987: 28; Neira, 1987: 260-61). The title of the poem uses metonymy to designate the subject of the piece as well as to introduce the national myth that is deconstructed in Otero's poem. The titular daughter of Yago is the Spanish nation, watched over by its patron saint, James the Great. According to legend, Saint James preached the gospel on the Iberian peninsula, and after his death his body was transported there and laid to rest at Santiago de Compostela. Saint James was invested with unparalleled iconographical significance in the construction of Spanish identity during the Middle Ages, when the Saint was reputed to have interceded on behalf of Ramiro I's Christian forces against the Moors in the mythical Battle of Clavijo of 834, some three hundred years earlier. ${ }^{6}$ During the Reconquest, the Saint's name was used as a battle cry by the Christian Spaniards. The invocation of Santiago, emphasizing his legendary representation as slayer of the Moors - combined with a military command to close the distance with the enemy and a vocative to Spain —-was subsequently popularized in a single refrain. ${ }^{7}$ While linguistically inscrutable in its assemblage of two vocatives joined by a verb, the phrase “ ¡Santiago, y cierra, España!” was sufficiently ingrained in the cultural imaginary by the seventeenth century for Cervantes to poke fun at it when he has a bemused Sancho Panza ask, “¿Está por ventura España abierta y de modo que es menester cerrarla, o qué ceremonia es esta?" (Cervantes, 2011: part II, chapter 58). “'Santiago, y cierra, España!” attained considerable political currency on the right in the 1930s when it was seized upon as an antirevolutionary slogan and call to patriotic and Christian duty. The phrase was emblazoned on the cover of the ultraconservative magazine Acción Española in a heraldic design that fused the chivalric and Cubist geometry. The emblem printed on the magazine is reminiscent of pictorial representations of Saint James in his guise as Moor-slayer, for example Giovanni Battista Tiepolo's iconic painting, and features the patriotic battle cry encircling an image of a horseman bearing a banner with the cross of Saint James. In Otero's poem, the Saint James legend and the related history of Christian conquest are viewed as symbols not of national heroism but of savagery. In the opening stanzas of "Hija de Yago," Otero establishes a parallel between geography and

\footnotetext{
6 The appearance of Saint James at Clavijo was recounted in medieval chronicles including the Historia legionense in the twelfth century and Rodrigo Jiménez de Rada's De rebus Hispaniae and Alfonso X of Castile's Estoria de España in the thirteenth. On the origins of the Santiago Matamoros myth and the political and ideological uses to which it was put by the Nationalists during the Spanish Civil War, see Giuliana Di Febo (2012: 49-54).

7 On the etymology of the refrain, see Lidwine Linares (2012).
} 
history, in which the contours of the Spanish peninsula are rendered as a metaphor for the brutal colonization of the Americas:

Aquí, proa de Europa preñadamente en punta; aquí, talón sangrante del bárbaro Occidente; áspid en piedra viva, que el mar dispersa y junta; pánica Iberia, silo del sol, haza crujiente.

Tremor de muerte, eterno tremor encarnecido, ávidamente orzaba la proa hacia otra vida, en tanto que el talón, en tierra entrometido, pisaba, horrible, el rostro de América adormida.

¡Santiago, y cierra, España! Derrostran con las uñas y con los dientes rezan a un Dios de infierno en ristre, encielan a sus muertos, entierran las pezuñas en la más ardua historia que la Historia registre.

(Otero, 2016: 232-33)

In Otero's acerbic interpretation of the country's historical destiny, Spain's location at the prow of Europe has predisposed it to a misguided quest for bloody conquest and subjugation of innocent peoples. In National-Catholic Spain, Columbus's 1492 voyage was commemorated as a foundational moment in Spanish national identity. The concept of Hispanidad promoted by the ultraconservative thinker Ramiro de Maeztu emphasized Spain's role within a community of Hispanic nations bound by language and the Catholic faith. Maeztu's doctrine of Hispanidad was a key ideological strand in the Franco regime's glorification of Spain's imperial past, and the anniversary of the discovery of the Americas, celebrated annually on the Día de la Hispanidad, attained an important role in the collective national identity projected by the regime (Aguilar \& Humlebæk, 2002: 137). In "Hija de Yago," Otero transforms a collective memory of national heroism into a symbol of national disgrace. Linking the colonization of the Americas to other shameful episodes of the country's past, Otero envisages the age-old rallying cry "¡Santiago, y cierra, España!” as a shibboleth that unlocks the latent meaning in disparate moments of Spanish history. The Reconquista, the colonization of the Americas, and the Spanish Civil War are manifestations of the bellicose religiosity given expression by the rallying cry, which encapsulates a national spirit based on the fusion of militancy and piety. Teasing out the connotations of the battle cry, Otero uses an image at once both martial and holy of an armour-clad God with lance at the ready to depict the haunting of Spanish history by a "Dios de infierno en ristre." The poet does not shy from pinning the country's current woes on this same unholy alliance of war and religion:

Alángeles y arcángeles se juntan contra el hombre.

Y el hambre hace su presa, los túmulos su agosto.

Tres años: y cien caños de sangre abel, sin nombre...

(Insoportablemente terrible es su arregosto.)

(Otero, 2016: 233) 
The unmistakeable reference to the civil war, expressed metonymically through burial mounds ("los túmulos"), the years of its duration ("tres años"), the biblical allusion to fratricide ("sangre abel") and the hunger brought it its wake ("el hambre hace su presa") — coupled with the linguistic echo of Falange in "alángeles" and the mention of angels ("arcángeles")— constitute a pointed attack on National Catholicism and on the Francoists' bloodlust ("arregosto"). The slogan " $i$ Santiago, y cierra, España!" serves as the conceptual hinge of "Hija de Yago," as Otero parses the historical significance of the phrase and uses it to denounce the national identity propagated by the regime and the perpetration of atrocities by the Nationalists in the civil war.

Whereas "Hija de Yago" denounces the regime by mining the historical significance of the slogans with which it is associated and through which it articulates its legitimacy, "Sobre esta piedra edificaré" achieves a similar aim by distorting and disfiguring these slogans. The apostrophe to a country moving backward in "Retrocedida España" is followed in the next two lines of "Sobre esta piedra edificaré" by further subtle mockery of the regime. The elegiac tone established by the apostrophe to a downtrodden nation helps to camouflage Otero's satire of the regime's economic maladministration in the subsequent lines. A prolonged drought dubbed the "pertinaz sequía" was among the regime's favoured excuses for the country's economic woes in the decade after the civil war (Harrison, 1995: 7). The issue of water scarcity was a common theme in Franco's speeches, and major hydraulic infrastructure projects were envisaged as a utopian remedy for the country's economic and social ills (Swyngedouw, 2007: 12). Building on a long tradition of redistributional water politics in Spain, the regime saw the problem of water scarcity as the result of natural territorial imbalances that could be corrected by technology. The solution was simply to transfer water from surplus river basins to deficit river basins through a massive expansion of the regulatory infrastructure, reservoirs, and dams, all brought under the control of a powerful centralized authority. The regime defended the transfer of water with the claim that it corrected a natural disequilibrium and constituted a just solution for the inequities that divided humid Spain and arid Spain (Swyngedouw, 2007: 12). These two Spains appear in "Sobre esta piedra edificaré" in an echo of the regime's hydraulic discourse: "agua sin vaso, cuando hay agua; vaso I sin agua, cuando hay sed." The mythological figure of Tantalus lurks behind Otero's image of a thirst that can never be sated despite an abundant supply of water. Otero reverses the word order in the first and second parts of the phrase: "agua sin vaso" becomes "vaso I sin agua," as the poet uses chiasmus to depict a hostile terrain vexed by the irreconcilable contradictions of its binary geography. Otero's Spain is a land where it rains either too much or not at all, a land where the rivers flow in torrents or where their beds lay stone dry. But the pervasive fatalism of these lines is undercut by a faint irony. The regime foregrounded the issue of water distribution as a distraction from the major socioeconomic inequalities that marked the post-war years. And here too, with a hint of dry humour, Otero reduces Spain's social problems to a question of water scarcity and defective redistribution. Overall, these lines amount to a damning assessment of one of the regime's flagship policies. Although Franco later realized his goal of increasing the country's distributional, irrigation, and hydroelectric capacities, the fact is that before 1955, for all the strident calls for dams and 
irrigation, the regime had relatively few achievements to show (Swyngedouw, 2007: 13-14). At the time Otero was writing, the dogged pursuit of economic autarky had impoverished the country to the extent that big public works of the kind necessary for Franco's water revolution were still a pipe dream (Swyngedouw, 2007: 13).

Otero's subversion of Francoist rhetoric attains its fullest expression in the final lines of "Sobre esta piedra edificaré" with the truncated quotation from the twelfthcentury Spanish chanson de geste the Cantar de mio Cid. The Cantar is an epic poem based on the life of the Castilian knight Rodrigo Díaz de Vivar, el Campeador, a celebrated military leader during the period of the Reconquista who famously conquered the city of Valencia and established an independent principality there. Díaz de Vivar, more commonly known by his soubriquet "el Cid," attained a legendary status after his death as a national hero. Given the regime's affection for the illustrious leaders of the medieval period and the Age of Discovery, it is unsurprising that the Cid played an important role in Francoist mythology. Franco's triumphal entry into Madrid on 18 May 1939 was envisaged as a re-enactment of the victory parade by Alfonso VI and the Cid following their conquest of Toledo (Preston, 2015: 411). Franco's supporters often compared him to the Cid, and it is clear that the Caudillo himself delighted in the comparison. Otero's quotation from the Cantar de mio Cid is therefore by no means innocuous and adds a certain acridity to the poet's attack: "Dios, qué buen I vasallo, I si oviesse buen...'। Silencio." The quotation is taken from the opening of the epic poem, which describes the Cid's banishment by the king because of a false accusation of financial wrongdoing. The hero's walk of shame through the streets of Burgos is greeted by a chorus of citizens who marvel at the Cid's valour. The citizens lament the absence of a master whom this gallant hero could serve. Otero's poem establishes a parallel between the poetic speaker's position on the margin of Spanish society and the Cid's exile. ${ }^{8}$ Like the Cid, Otero's poetic persona is obliged to retreat from a life of service to his nation's ruler. Otero rejects the state of vassalage that is denied to his medieval counterpart. Unlike the traditional court poet, Otero will not serve his ruler with these verses, rather he will expose the hypocrisy of the Francoist state and bear witness to the misery it inflicts on its people. As well as to the poetic speaker, the quotation from the Cantar applies to Spain. The final stanza opens with an apostrophe to "Retrocedida España," which suggests that the "vasallo" of the final lines is the country itself. The quotation from the Cantar elides the word "señor" from the original text in an emphatic articulation of the idea that, for all Franco's pretensions, a leader is precisely what the country lacks. In his reproduction of the quotation, Otero uses enjambment to cleave the word "vasallo" from its preceding adjective: "Dios, qué buen I vasallo." The syntactic break leaves "vasallo" on a separate line, placing substantial stress on the word and heightening the force of the aposiopesis in the next line: "si oviesse buen..." The missing "señor" is parallel to the strong "vasallo" of the preceding line, and its absence therefore strikes the listener doubly hard. Otero ends the poem with an arresting image of Spain as a vassal without a cause, a rudderless ship of state cast adrift in high seas.

\footnotetext{
${ }^{8}$ On the parallels between the Cid and Otero, see Armando López Castro (2008: 461-62).
} 
This article has illustrated some of the ways Blas de Otero parodies the rhetoric of Franco's authoritarian regime. Well attuned to the idiosyncrasies of Francoist dogma, Otero weaponizes the regime's discourse through a process of allusion and direct linguistic borrowing. In his poetry, these allusions and Francoist loanwords are transformed into a target of subtle yet blistering satire. Otero's 1955 collection Pido la paz y la palabra exhibits an endeavour to wrest control of the written word from the regime. The poet's critique of National-Catholic mythology is inherently subversive and forms part of Otero's engagement with the social and political injustices of his time. In its close reading of "Sobre esta piedra edificaré" and of "Hija de Yago," this article has suggested that Otero undermines National-Catholic rhetoric and myths in the service of a contrarian politics that calls attention to the necessity of an alternative model of national reconstruction. Otero's poetry illustrates the value of language in desperate and indeed dangerous times. By taking a scalpel to the regime's vision of Spain, Otero was able to peel away the layers of deceit and offer different ways of reflecting on his country and its people at a time of crisis.

In an evaluation of the ways his own work responds to the socio-political circumstances of its composition, Ángel González, fellow poet and close contemporary of Otero, argues that irony was one of the key literary effects that enabled González and other poets of his generation to get their work past Franco's censors:

El uso de la ironía fue, en principio, otro imperativo de la situación. Como es sobradamente sabido, los textos irónicos exigen que el lector invierta el recto significado de las palabras; operación mental que, aunque sencilla, desbordaba de hecho la capacidad intelectiva de muchos censores, primera ventaja de un procedimiento que implica además la relación y consiguiente comparación evaluativa de dos puntos de vista opuestos. Así, el procedimiento resultaba doblemente útil: permitía burlar las normas vigentes en materia de censura, y era de una gran eficacia crítica. El poema titulado "Discurso a los jóvenes" cumplió satisfactoriamente, a mi modo de ver, esos objetivos, aunque yo había intentado en él una simple parodia divertida de las irritantes arengas políticas entonces habituales. El poema fue para mí, en ese aspecto, un hallazgo. Desde entonces, la ironía pasó a ser uno de los más constantes componentes de mi poesía. (González, 2008: 20-21)

To González's mind, irony was a key component of the poetic armoury of the period and enabled writers to sharpen the bite of their testimonial gaze on Spain's past and present. González adduces his parody of Francoist language in "Discurso a los jóvenes" (2008: 75-77) as evidence of the subversive potential of poetic discourse in the 1950s and 1960s. The procedure described by González, in which the regime's style of discourse is observed and reproduced from an ironic distance, encapsulates the method implicit in the poems explored in this article. Blas de Otero had his fair share of run-ins with the censors, and his work was subject to the mutilations of self-censorship, but Pido la paz y la palabra illustrates the extreme lengths to which poetic subversion could be carried while managing to evade the regime's cultural police. Albeit subtle, or perhaps because of their very subtlety, this discursive borrowing from the regime and this repurposing of Francoist rhetoric in a dissident context are some of the most effective mechanisms by which artists sought to challenge 
the regime and its monopoly on the discursive elaboration of reality. Works of prose, such as Juan Marsé's Sí te dicen que caí (1973), which famously uses a line from the Falangist "Cara al sol" in its title, show evidence of similar parodic techniques at work. Blas de Otero's work illustrates the process by which the regime's own linguistic tools were turned against it, as Francoist slogans and catchphrases were emptied of their intended meaning and reappeared in a new, critical context of poetic forms that protested against the same realities the regime sought to suppress with its language of self-aggrandizement and obfuscation.

Open Access This article is licensed under a Creative Commons Attribution 4.0 International License, which permits use, sharing, adaptation, distribution and reproduction in any medium or format, as long as you give appropriate credit to the original author(s) and the source, provide a link to the Creative Commons licence, and indicate if changes were made. The images or other third party material in this article are included in the article's Creative Commons licence, unless indicated otherwise in a credit line to the material. If material is not included in the article's Creative Commons licence and your intended use is not permitted by statutory regulation or exceeds the permitted use, you will need to obtain permission directly from the copyright holder. To view a copy of this licence, visit http://creativecommons.org/licen ses/by/4.0/.

\section{References}

Aguilar, P., \& Humlebæk, C. (2002). Collective memory and national identity in the Spanish democracy: The legacies of Francoism and the civil war. History and Memory, 14(1-2), 121-164.

Alarcos Llorach, E. (1997). Blas de Otero. Nobel.

Barbosa-Torralbo, C. (1994). Poesía como diálogo: La voz poética de Blas de Otero y su recepción. Libertarias.

Barral, C. (2001). Memorias. Península.

Cervantes, M. de. (2011). Don Quijote de la Mancha. Francisco Rico (Ed.). Santillana.

Debicki, A. P. (1999). Poetry and culture, 1936-1975. In D. T. Gies (Ed.), The Cambridge companion to modern Spanish culture (pp. 187-197). Cambridge University Press.

Di Febo, G. (2012). Ritos de guerra y de victoria en la España franquista. Universitat de Valènica.

Eiroa San Francisco, M. (2012). Las fuentes doctrinales: Pensamiento y lenguaje de la represión sistémica (1936-1948). In J. Aróstegui (Ed.), Franco: La represión como sistema (pp. 107-160). Flor del Viento.

Gónzalez, A. (2008). Poemas (14th ed.). Cátedra.

Gracia, J. (2004). La resistencia silenciosa: Fascismo y cultura en España. Anagrama.

Gracia, J. (2006). Estado y cultura: El despertar de una conciencia crítica bajo el franquismo, 1940_ 1962. Anagrama.

Harrison, J. (1995). The Spanish economy: From the civil war to the European Community. Cambridge University Press.

Labanyi, J. (1995). Censorship or the fear of mass culture. In H. Graham \& J. Labanyi (Eds.), Spanish cultural studies: An introduction (pp. 207-214). Oxford University Press.

Lanz, J. J. (2008). Alas de cadenas: Estudios sobre Blas de Otero. Renacimiento.

Linares, L. (2012). ¡Santiago y cierra, España! Les Cahiers de Framespa, 10, https://doi.org/10.4000/ framespa.1552. Accessed 23 March.

López Castro, A. (2008). El Cid en la literatura española a partir de 1939. Cuadernos para Investigación de la Literatura Hispánica, 33, 455-468.

Marsé, J. (1973). Si te dicen que caí. Novaro.

Montejo Gurruchaga, L. (1998). Blas de Otero y la censura española desde 1949 hasta la transición política: Primera parte: De Ángel fieramente humano a En castellano. Revista de Literatura, 60(120), 491-516. 
Neira, J. (1987). La edición poética en la España de postguerra: Pido la paz y la palabra (1955). Anuario de Estudios Filológicos, 10, 251-264.

Otero, B. de. (1942). Cántico espiritual. Cuadernos del Grupo Alea.

Otero, B. de. (1955). Pido la paz y la palabra. Cantalapiedra.

Otero, B. de. (1987). Correspondencia sobre la edición de "Pido la paz y la palabra". J. Neira (Ed.). Hiperión.

Otero, B. de. (2016). Obra completa (1935-1977). S. de la Cruz \& M. Hernández (Eds.). Galaxia Gutenberg.

Payne, S. (1999). Fascism in Spain: 1923-1977. University of Wisconsin Press.

Pemán, J. M. (1939). La historia de España contada con sencillez. Escelicer.

Preston, P. (2014). The great manipulator: Francisco Franco. In D. Baratieri, M. Edele, \& G. Finaldi (Eds.), Totalitarian dictatorship: New histories (pp. 83-102). Routledge.

Preston, P. (2015). Franco: Caudillo de España. Debate.

Swyngedouw, E. (2007). Technonatural revolutions: The scalar politics of Franco's hydro-social dream for Spain, 1939-1975. Transactions of the Institute of British Geographers, 32(1), 9-28.

Publisher's Note Springer Nature remains neutral with regard to jurisdictional claims in published maps and institutional affiliations. 